diseases, compiled by the Chief Veterinary Officer of the Protectorate, should be read in conjunction with the author's chapter on cattle. With reference to measures adopted to combat the spread of rinderpest, there is an interesting illustration showing the method of hyperimmunising cattle.

The book concludes with a chapter detailing the assistance furnished by British East Africa and the sacrifices made by both Europeans and natives in furtherance of the military operations which resulted ultimately in the conquest of what is now known as Tanganyika Territory.

Those who, like Lord Cranworth, have the interests of British East Africa at heart will welcome this volume, with its purpose of bringing to the Protectorate an influx of recruits of the right standard requisite to further the development of its resources, particularly in view of the existing demand for the raw materials required in the reconstruction of the Empire's industries.

\title{
Weather Notes of Evelyn, Pepys, and Swift in Relation to British Climate.
}

\author{
By Capt. C. J. P. Cave,
}

THE interest in weather notes from old diaries lies in the fact that they may throw some light on the vexed question whether meteorological conditions in Western Europe are changing. The diaries of Evelyn and Pepys have been quoted by both believers and unbelievers in changing conditions, and it must regretfully be admitted that the question is, as yet, by no means easy to answer. Evelyn's diary extends from 1620 to 1706 , but during this long period there are, on the average, only about eight weather notes to every three years. As a rule, we find only very outstanding phenomena recorded, such as serious droughts, great storms, or hard frosts. Evelyn's diary has, however, never been published in full, and it is quite possible that the complete diary may contain a great deal more information on the subject. Pepys's diary extends only from 1660 to 1669 , and is, therefore, too short to enable us to draw any safe conclusions. His weather notes are, however, far more numerous than Evelyn's, there being remarks bearing on the weather on an average of sixty-two days a year. Like Evelyn, he mentions outstanding features, but he also frequently mentions the weather as it affected his movements or his health, so that we get a much better record for the few years during which Pepys kept a diary than we do for the longer period from Evelyn. Neither writer is by any means infallible in his recollection of past weather, and both can be confuted from their own writings regarding events that they describe as unprecedented in their memories.

The most significant facts from which to gauge weather conditions, in times before instrumental readings, are hot summers, droughts, wet spells, and cold winters. So far as hot summers are concerned, we have little to go on. Both writers complain of the heat at times, but the only really exceptionally hot summer seems to have been that of 1698 , mentioned by Evelyn. Nor do we get very much ground to go on in droughts and wet spells. We are, therefore, restricted to cold winters, and especially to the freezing of the Thames, for evidence of any change in climate between the seventeenth century and the present time. The evidence was discussed by several writers in Symons's Metcorological Magazine in rir I and 1912, and different writers came to NO. 2639 , VOL. IO57 diametrically opposite conclusions. Mr. Walter Sedgwick maintained that the intensity of falls of snow was likely to be exaggerated by the seventeenth-century diarists, for when roads were normally bad, traffic would have been far more seriously affected by snow than it is to-day. Mr. W. H. Dines, on the other hand, contended that when roads were always bad during the winter, "it was a matter of indifference whether roads were blocked by snowdrifts." It is also said that the number of references to snow in Evelyn's diary are very few, but it is quite certain that we do not find references to snow on nearly all the occasions when it occurred. In December, 1648, Evelyn says: "This was a most exceeding wet year-neither frost nor snow all the winter for more than six days in all "; but none of these six days are otherwise mentioned in the published diary. The winter of $1657-58$ was extremely cold, and it is almost certain that there must have been snow; but none is specifically mentioned.

It is certain that the Thames in London froze more often in the seventeenth than in the nineteenth centuiy, but some hold that this was due to. the fact that the river was not embanked, and that Old London Bridge offered such an obstruction that the water above the bridge froze more easily than it does to-day. The Thames in London is recorded to have been frozen, or nearly frozen, on seven occasions during the period over which Evelyn kept his diary, and it is almost certain that it must have been frozen also in 1658 . It is noticeable that the freezing in November, 1662 , is mentioned by Evelyn, but not by Pepys, while the freezings of December, 1665 , and January, $\mathrm{r} 667$, are mentioned by Pepys, but not in the published diary of Evelyn. It seems as though the freezing of the Thames was not looked on as such a very out-or the-way event, while slight frosts or small falls of snow might pass unnoticed. There were, of course, winters when there was little or no frost or snow, but they were looked on as very exceptional, and caused much apprehension as likely to "threaten a plague," and fasts were ordered by Parliament to pray for "more seasonable weather."

From the evidence in Pepys's diary the present writer thought at first that "there seems no reason to suppose that the weather" in the seventeenth 
century "differed much from that to-day," 1 but a further consideration of Pepys's notes, taken in conjunction with those of Evelyn, has led him to modify his views, and he now thinks that, on the whole, there is a good case for supposing that the winters in the seventeenth century were more severe than they are to-day. Sir John Moore, it is true, maintained in a paper, "Is our Climate Changing?" read before the British Association (Section A) in 1908 , that the British climate is not changing; his evidence is based mainly on observations during the nineteenth century, with some from the eighteenth; but the constancy of the climate during the nineteenth century does not seem to preclude a change having occurred since the seventeenth, nor does it follow that a change should be progressive.

There must, however, be a good deal more evidence in scattered letters or diaries that will in time throw more light on this important point. In Swift's “Journal to Stella," which extends only from 17 IO to $I 7 I_{3}$, there are weather references on seventy-eight days a year. The period is short, but I think it bears out the contention that winters with little frost or snow were exceptional. On December 27, 1710, Swift writes: "Did you ever see so open a winter in England? We have not had two frosty days." This was probably a I (Quart. Journ. Roy. Met. Soc., vol. xilvi., p. 68. facon de parler, for at least two frosts are mentioned previously, and one fall of snow. By a frosty day it must be supposed that the diarists meant more than a slight morning frost of one or two degrees in the screen. If this is so, the warmth of the early winter in 1710 was not very exceptional, judged by present-day standards. December 27 , it must be remembered, corresponds to January 8 new style, but in the last fifteen years during which the writer has kept climatological records there have been four, if not five, winters when there has been no frost worth speaking about until after the middle of January, in Hampshire at any rate, and these were probably as "open" as the winter of I7 IO.

Swift, on the whole, takes rather more interest in the weather for its own sake than does Pepys. He compares notes with "Stella" on the difference between the weather in Ireland and in London, but, of course, most of the references concern the weather as it affected him personally. There are many complaints of cold, wet, and heat, and Swift seems to have had a constitution that was much affected by hot weather. It is curious to find that bad weather is frequently made an excuse for dining with Mrs. Vanhomrigh at the time when Swift was begrinning that acquaintance with her daughter "Vanessa "which was fraught with so much tragedy.

\section{Optical Instruments in Industry.}

$\mathrm{O}$ PTICAI, instruments, which proved their worth in war, are now being more and more utilised in developing the arts of peace. A short account of some of the chief applications of these instruments to industrial requirements, especially the more recent uses, may therefore be not without intercst at the present time.

Passing over the microscope with a brief reminder of its modern use, in metallurgy, for showing the structure of iron and other metals, one of the first instruments to note is the refractometer. In many chemical works this, in one form or another, is invaluable as a means of controlling the various operations, by reason of the simplicity of its manipulation and the rapidity with which the results are obtained. The refractive index suffices in numerous instances to determine the strength of chemical solutions. It is ascertained in a few minutes, and only a drop or two of liquid is required for the purpose if an instrument of the Abbe type is employed. No weighings are involved, and no calculations if the temperature is suitably controlled, so that liability to error is greatly minimised. The instrument is thus almost an ideal one for the control of works operations where the degree of strength or purity of a product is required to be ascertained by means of rapid tests, or where a process has to be stopped when the product has reached a certain stage. Specific gravity determinations or simple chemical titrations are often used in such cases, NO. 2639 , VOL. IO5] but the refraction method is always quicker, is generally more accurate, and sometimes possesses other marked advantages. Thus the strength of an aqueous solution of nicotine can readily be obtained, correct within about 0.1 per cent., by the refractometer, whereas the specific gravity method is of no value in this instance, and titration results are vitiated if other basic substances, such as ammonia, are present.

Acetic acid, acetone, ammonia, ammonium sulphate, carbolic acid, cream of tartar, glycerin, and saltpetre may be mentioned as products, made on a large scale, for which the instrument is useful. In the brewing industry the determination of alcohol, extract, and original gravity of beer is readily made by means of the refractometer. In the fats and oils industries, in the fractionation of petroleum products, in the distillation of tar oils, and in the manufacture of many pharmaceutical articles, the refractive index is a valuable aid for controlling the purity of the materials and finished products. It is useful also in the manufacture of various viscous mixtures or semi-solid pastes, in order to determine whether the constituents have been adequately mixed, and thus to obviate local excess or deficiency of the active ingredients.

The polarimeter is an instrument constantly in use for the evaluation of essential oils, whilst makers of starch products, tartaric acid, and alkaloids frequently have recourse to it, and a 